\title{
A Conversation with Ungulani Ba Ka Khosa ${ }^{1}$
}

\section{Sophia Beal}

Tulane University

Francisco Esaú Cossa was born on 1 August 1957 in Inhaminga in the province of Sofala, Mozambique. A member of the Tsonga ethnic group of Southern Mozambique and a speaker of Tsonga, the author goes by his Tsonga name: Ungulani Ba Ka Khosa. Khosa attended elementary school in Sofala and high school in Zambézia. He holds a bachelor's degree in History and Geography from the Universidade Eduardo Mondlane in Maputo.

Khosa, who taught high school for years and briefly worked for the Mozambican Ministry of Education, began his literary career publishing short stories and co-founding Charrua, a magazine of the Associação dos Escritores Moçambicanos (Association of Mozambican Writers), of which he is a member. During the 1990s, he wrote crónicas for various newspapers. He now works as the Director of the Instituto Nacional do Livro e do Disco (National Institute of the Book and Disc).

The author of six books, Khosa's career took off with the 1987 publication of Ualalapi. The text won the Grand Prize of Mozambican Fiction in 1990, and in 2002, a panel of judges in Accra, Ghana ranked Ualalapi one of the 100 best works of African fiction of the $20^{\text {th }}$ century. Next, Khosa published two collections of short stories, Orgia dos Loucos (1990) and Histórias de Amor e Espanto (1993), followed by the novel No Reino dos Abutres (2002). His novel Os Sobreviventes da Noite (2005), a portrayal of the use of child soldiers and child concubines in the Mozambican war of destabilization, won the José Craveirinha Award in 2007. This interview primarily focuses on Khosa's most recent novel, Choriro, published in 2009 by the Mozambican publishing house Alcance. 
Sophia Beal: In Choriro you tell the story of the death of a king (mambo) of the territory north of the Zambeze River, at the end of the nineteenth century. This king, Luís António Gregódio (known as Nhabezi), unlike other kings in the region, is a white Portuguese man. The omniscient narrator jumps from one period to another, recounting aspects of the king, his three wives, and their mestiço children's lives and of the regional commerce and customs. At various times, the narrator, always using the past tense, refers to future events using expressions such as "anos depois viria saber" (years later would come to know). Could you speak about this tactic of mixing various temporalities? Did it influence your decision to have an omniscient narrator instead of narrating the novel from the point of view of a character?

Ungulani Ba Ka Khosa: To be honest, Sophia, it wasn't a premeditated, carefully considered act. The text induced me to use that technique, which you all call omniscient narration. Much like the griots, those storytellers that swarmed pre-colonial Africa in the western part of the continent, the text led me to that framework. To conclude: there was no model or sketch. The text, the characters, and the historical setting presented the shortcuts, the paths I traveled down. I am probably behaving like a crab: traveling in the present as I walk in the past.

SB: What does choriro mean?

UBKK: Choriro is a corruption of the noun choro (cry, crying). During the time of the story, the current cultural practices in the bordering states were incorporated into the prazos [large estates common in the Zambezi River Valley that were aimed at resource extraction and operated by Portuguese traders]. When the king, or mambo, died, a mourning period took place that was characterized by its controlled chaos. During that period of absence of power in the prazos and later in the military states of the Zambeze Valley this period became known as choriro: crying, mourning, absence of power. During the Monomotapa Empire, the death of the emperor caused, for a period of three or more days, a scenario of chaos to evoke the absence of power. With 
the enthronement of the new emperor, order was reestablished. These practices were incorporated into the prazos-social formations that combined values from the matrilineal northern side and the patrilineal southern side of the Zambeze River.

SB: A stirring scene in the novel Choriro takes place just after the wedding of Nhabezi and his third wife, Nzinga, the daughter of another king of the region. Still a virgin and fearful of the "espécie andante sem pele" (walking species without skin) - the only white person she has ever seen-she "mostrou-se arredia em partilhar a cama com Nhabezi" (appeared timid about sharing a bed with Nhabezi) (44). In a novel with significant historical description, could you speak about your choice to develop the plot more dramatically in this scene?

UBKK: It is the unknown, Sophia. Remember García Márquez’s description of an indigenous character who saw himself in a mirror for the first time? The author says the man went crazy. Imagine what goes through the head of a black person from the most distant backlands on having contact, for the first time, with a white person?

SB: Moreover, it is in this same scene that Suna, Nzinga's slave, suddenly resolves the conflict. Could you talk about Suna, a character who unexpectedly wields significant power and influence?

UBKK: These are small powers. In the courts, it was common practice for there to be nursemaids who dedicated their soul and body to the education and amusement of princesses. They gave into the wills of the princesses, but, simultaneously, they were, in a subtle way, sinuously influencing the personality of the ladies with whom they lived. There was quite a significant web of complicity. They were, in more rigorous language, the domestic slaves. Their role was to serve the ladies of the court. Many grew up with the ladies of the court who protected them. Their age differences were minimal. I'd venture to add that the nursemaids had quite strong power over the princesses' attitudes about certain actions. They were, at heart, the great accomplices of the ladies. 
SB: Modes of communication are a major concern in the novel. For instance, Nhabezi, a former elephant Hunter, uses gestures unfamiliar to the court whose older members "assustavam-se com os pequenos e freqüentes gestos de mãos abrindo-se em leque do Nhabezi, hábito herdado dos tempos das caçadas em que as ordens se faziam, usualmente, por gestos" (were startled by Nhabezi's small, frequent gestures in which his hands fanned out, habits inherited from the time of the hunts in which orders were usually given with gestures) (41). Nhabezi, who deserted the imperial army, refuses to speak Portuguese, even though his son wants to learn the language. Could you talk about your interest in languages and communication, themes present in almost all of your stories and novels?

UBKK: My great passion is in proverbs and the joy I get from recreating them in dialogues that cause me a lot of work and pleasure. At the time of my stories, the proverb served a crucial role in the system of communication. You know that Mozambique is characterized by a diversity of Bantu languages and a multiplicity of customs. Therefore, upon entering these particular cultures I had to attach myself to these details that necessarily occur via modes of communication.

SB: In Choriro, as in your books Ualalapi, No Reino dos Abutres and Os Sobreviventes da Noite, characters respond to proverbs with other proverbs, creating, in certain cases, dialogues composed almost entirely of this type of expression. Does this type of dialogue indeed exist or do you take poetic license to evoke something in particular? I would like to know more about the inclusion of proverbs in your writing.

UBKK: That type of dialogue emerges in a universe with a strong enculturation of local values. Usually, the dialogue takes place between adults. When I introduce a young person in that type of dialogue, I try to show an educational system that frequently existed outside the standard institutions. These dialogues no longer have the same weight. The educational value of national languages is losing its importance. Actually, in the presence of a proverb, my desire is to create another adage. This task is not always easy if we consider that a maxim is the result of a deeply-rooted cultural practice. But it's a literary exercise that fascinates me. 
I agree with you entirely when you say that this form of communication gains a poetic value today by evoking a time, a historical portrait that is lost in memory. Today's educational systems have adopted other standards for their teaching methods.

SB: While most Mozambican fiction is set in the twentieth century, your texts frequently portray earlier periods. This is the case with your most well known work, Ualalapi, which tells the story of conflicts between N'gungunhana, the ruler of the kingdom of Gaza, and the colonial Portuguese who overthrew his kingdom in the late $19^{\text {th }}$ century. The book is difficult to categorize, as it could be considered a collection of interrelated short stories or a loosely woven novel. It was named one of the hundred best works of African fiction of the twentieth century, and it fills a gap that would be impossible to fill historically due to a lack of documentation. How did you decide to tell this story?

UBKK: It was the impulse of a history teacher, wanting to tell the reverse of history that, actually, should be the obverse, the effigy, the true face of the history of the Gaza Empire. Actually, my country hunted for myths, needing historical characters who personified heroic legends. N'gungunhana was one of the chosen. And I, humbly, tried to humanize that myth. I portrayed it via orality, oral history, as it was transported through time. Therefore, what I did was step out of history manuals and step into the meanderings of orality. And Ualalapi is just that: the unofficial gaze.

SB: I am curious about the reception of your fiction in a country in which a little less than half of the population is literate. Do you know if any of your books are part of the curriculum at any Mozambican schools?

UBKK: Actually, two of my books are mandatory high school reading: Ualalapi and Orgia dos Loucos. There are stories from As Histórias de Amor e Espanto that are included in high-school course packets. And what shocks me is that the books manage to survive. I say this because mandatory reading runs the risk, the majority of the time, of boring young people, causing them to adopt a 
passive attitude about the texts. Much to my amazement, my texts become current: today's readers identify with the stories and make them contemporary. There are young people, I should mention, who still think that I painted a faithful portrait of Emperor N'gungunhana. They think it isn't fiction. It's gratifying.

SB: In 2005, you published the novel Os Sobreviventes da Noite, which focuses on one of the most distressing aspects of the war of destabilization: the use of child soldiers and child concubines. Two terms hover over the novel's pages, although they never appear in print: Frelimo [Frente de Libertação de Moçambique], the ruling party, and Renamo [Resistência Nacional Moçambicana], the internationally-financed rebel army that sought to destabilize the state. Why did you choose to omit their names? What effect did you hope to cause or avoid?

UBKK: Actually, my concern in Sobreviventes wasn't so much to look at Frelimo or Renamo. A larger concern was to enter the soul of the child soldier. I was concerned and I'm still concerned about a phenomenon that extends throughout Africa: the growing use of children in armed conflicts. I didn't want to avoid anything. Besides, literature, the truly literary text, doesn't avoid, it incorporates. Frelimo and Renamo weren't my concern. My soul was with the child soldiers. I believe it's a scenario that just as easily could have occurred in Mozambique or Uganda or Liberia. The denominator is the same: the instrumentalization of the child. Those names, Frelimo and Renamo, have little value in the great tragedy that is the instrumentalization of children. Those perversities, the dehumanization of children, are what we're interested in retaining, so that History doesn't repeat itself. Looking at it with some distance, I think that Os Sobreviventes da Noite probably is my most militant book. It's an engagé text, excuse the expression.

It's obvious that in situations as terrifying as the dehumanization of children, someone should be held responsible. I know it's necessary to find the authors of such ethically appalling acts. I know that, but my domain, writing, took me to a scenario in which the conditions of peace are totally obliterated. In conversations, no one puts the future of the child soldiers on the table. It's taboo for politicians. They speak of the integration and reintegration of men, of 
troops, but never of child soldiers. The grotesque, much of the time, is to make peace accords without addressing the child soldiers... Actually, many pages could be written about the topic.

SB: In Choriro, you write about a time when elephant hunters were becoming slave traffickers in the Zambeze Valley because humans were more lucrative than ivory. Some of the scenes about the treatment of these slaves are shocking, such as when "em dias santos, era obrigar os escravos a assistir à missa aprisionados por cordas e forquilhas" (on holy days, the slaves were forced to attend Mass imprisoned by cords and forked poles) (88). What did you learn about the slave trade in your research for Choriro? Were there details that surprised you?

UBKK: That material is part of my professional and academic area. Remember that my academic training was in the field of History and Geography for Educators. I taught history for various years. On the ballast of my boat, the slave trade is a recurring theme, though not necessarily an obsessive one. It's our history, it's a source of knowledge. To take on the slave trade is not a cathartic exercise, but a way of assuming responsibility for our history with the serenity that it deserves.

SB: Transmutation is a central theme in Choriro. Nhabezi wants, upon dying, to be transformed into a Lion or another powerful animal as, according to legend, happens with the black kings of the region. But "os espíritos antigos e novos não aceitarão o espírito do branco que se fez preto na fala e nos costumes" (the old and new spirits will not accept the spirit of a white man who made himself black in his speech and customs) (109). Could you speak about your interest in transmutation?

UBKK: Upon delving into Bantu cosmogony, transmutation is a recurring theme. To speak of spirits that wander at night, bothering or protecting the living, is very natural. Whoever enters into this world has to have an uncomplicated gaze and an open mind. Fiction ends up winning. I believe that LatinAmerican magic realism contributed immensely to allowing African literature to go in new directions. Until then, our literature never wanted to let go of the western concept of obscurantism toward paranormal phenomena. African 
literature adopted a political stance, very directed at attacking neocolonial phenomena. To be on the left at the time implied adopting a materialist view of History. The cultural values imbued in a certain mysticism had no place on the literary menu in vogue at that time.

SB: Fascinating. Do you see much dialogue or interrelation between African writers who write in different languages?

UBKK: Our big problem lies in the fact that our route to internationalization passes, necessarily, through the capitals of the old colonizing powers. A Cameroonian writer has to make his mark in Paris, a Nigerian, in London, a Mozambican, in Lisbon. This is the price we still have to pay. The most grotesque example is in Mozambique. There is a relatively strong editorial market in South Africa just 400 or 500 kilometers from the Mozambican capital, but there is no exchange, much less a market for translation. The cultural politics of Africa are still not a priority. The so-called renaissance africaine is still a political cliché with doubtful contours. African writers only meet one another in European cultural capitals and beyond the Atlantic. I'm of the school that says development has to advance with the waves that break successively on the beach. In other words, politics has to be sustained by a tripod on which the Cultural, Social, and Economic legs all bear equal weight. These areas have to travel on the same wavelength.

To respond objectively to your question, I'd say no, there isn't dialogue among African writers. And I believe that the language barrier, at present, can't serve as a justification. On the other hand, I believe that there is little sense of solidarity among African writers. When a writer breaks through the barrier and becomes internationally known he is unconcerned about arguing that a national literature is not made up of one author, but many. The comprehension of a national literature occurs through hearing different sonorities. Latin America is an example of this type of pendulum effect. Each great author of a country within the Latin-American mosaic functioned as a flag for the knowledge of the true national literary anthem. It's possible that many argue saying that the majority of African writers is in the diaspora. Personally, I won't get behind 
that diapason. I think that the growing democratization of African countries subordinates the question of political exiles. The great challenge that Africa will have to face for its affirmation will come from Culture with a capital c. And in that Culture, literature enjoys a preponderant role.

SB: You work at the Instituto Nacional de Cinema e Audiovisual de Moçambique (National Cinema and Audiovisiual Institute of Mozambique). Does this work influence your fiction?

UBKK: Actually, I stopped working at the Instituto Nacional de Cinema e Audiovisual de Moçambique. I'm now at another institute: that of the Book and Disc. I thought, when I started working at the Instituto de Cinema, that contact with the moving image would benefit my literature. But my expectations were addled. The world of cinema in Africa is still in its pre-history. The filmmakers we have don't value writers and literary texts very much. That marginalization has to do, in part, with economic pressure deterring investment in fiction. There isn't investment in cinematic fiction. And when there is, the producer has the last word. No exchange of texts and ideas brings the writer and filmmaker together. The worst is when the filmmaker takes on the responsibility of being the screenwriter as a way of cutting costs and maximizing profit. What ends up losing is Cinema with a capital $c$.

My work at the institute was administrative, not creative. I participated in earnest in one or two scripts, beyond writing some national news films, here called Kuxa-Kanema. These national news films died with the impact of television. In their golden age, many people went to the cinema just to recognize themselves in the images of the country that came on screen. It was fifteen minutes of real empathy between the image and the public. Those were other times... But cinema continues to be my passion for its intellectual, artistic, and playful components.

SB: Before wrapping up, would you like to add anything?

UBKK: The final period, Sophia. 


\section{Note}

1 Interview conducted in Portuguese via an email exchange that took place in August and September 2010. Translation into English by Sophia Beal.

Sophia Beal is a Mellon Postdoctoral Fellow in the Humanities at Tulane University in the Department of Spanish and Portuguese, affiliated with the Program for African and African Diaspora Studies. She earned her PhD in Portuguese and Brazilian Studies in 2010 from Brown University. In 2005, Beal completed a Fulbright grant in Maputo where she studied Mozambican literature. Her recent work focuses on questions concerning urban development and public works in $20^{\text {th }}$-century Brazilian fiction. 